\title{
GEOTECHNICAL PROPERTIES OF NAJRAN SOIL, KINGDOM OF SAUDI ARABIA
}

\author{
Ammar Rouaiguia and Mohammed A. Dahim \\ Civil Engineering Department, College of Engineering, Najran University, Saudi Arabia \\ E-mail:rouaiguia@yahoo.com
}

\begin{abstract}
Collapsible soils consist of loose, dry, low-density materials that collapse and compact under the addition of water or excessive loading. These soils are distributed throughout the world, specifically in areas of young alluvial fans, debris flow sediments, and loess (wind-blown sediment) deposits.

The basic objectives of this study are to describe the properties and characteristics of collapsible soils such as: Origin and occurrence, structure, and composition of collapsible soils. This study also investigates the collapsibility characteristics and behavior of the materials with particular reference to their response to wetting under different stress levels. Undisturbed soil samples from Najran area situated in the south of Saudi Arabia have been collected and studied by using both single and double oedometer tests. The results show that the highest value of collapse potential $(\mathrm{CP}=11.07 \%)$ of Najran soil as given by double Oedometer tests which represents a severe trouble according to [1].
\end{abstract}

Keywords: Collapsible soil, Najran soils, Oedometer tests.

\section{INTRODUCTION}

Conditions in arid and semi-arid regions, like the case of Najran area (south of Saudi Arabia) represent the formation of the most problematic collapsible soils. The mechanisms that account for almost all naturally occurring collapsible soil deposits are debris flows, rapid alluvial depositions, and wind-blown deposits (loess).

Collapsible soils consist of loose, dry, lowdensity materials that collapse and compact due to the addition of water or excessive loading. In other words, these soils are susceptible to large volumetric strains when they become saturated. Soil collapse occurs when the soil is saturated at depths greater than those reached by rain effect. This saturation eliminates the clay bonds holding the soil grains together [2]. Similar to expansive soils, collapsible soils result in structural damage such as cracking of the foundation, floors, and walls in response to settlement. In one particular case of soil collapse, 14 houses in a Cedar City, Utah neighborhood had to be jacked off their foundations and relocated due to severe settlement [3].

Collapsible soils cover more than $10 \%$ of the nation's territory [4]. Loess is one type of collapsible soils, which is an aeolian sediment that forms by the accumulation of windblown silt and lesser and variable amounts of either sand or clay. Loess is created in one of two environments: either in a peri-glacial environment, at the edge of glaciers; or in desert and interior basin regions. Loess soils exhibit considerable strength and stiffness in their dry, natural state but settle dramatically when they become wet, even under overburden pressure. 
According to [5], many common features are found in most of loess soils include: an open metastable structure, a high voids ratio and low dry density, a high porosity, a geologically young or recently altered deposit, a deposit of high sensitivity, a soil with inherent low interparticle bond strength. The open structure of collapsible soil is maintained by a natural bonding process between the soil particles, which under very low overburden pressures does not need to be very strong. As subsequent deposition occurs very slowly, additional bonding develops that the open structure to be (largely, at least) maintained. It is this bonding that causes the metastability, since some additional external factor (such as significant static or dynamic loading or wetting) is necessary to destroy the bonds/overcome the bonding strength. Once the bonding is no longer effective, the particles become free to develop a stable state under the prevalent environment and loading conditions. A clear understanding of the controls on this bonding and bond deterioration process is evidently necessary if collapse is to be predicted and or prevented.

The mineral quartz is most dominant in loess with feldspars, carbonates, and clay minerals present in smaller amounts. For instance, in arid regions loess contains larger amounts of calcium carbonate; whereas, in humid regions clay minerals in loess are more prevalent. Desert regions of the world may be thought of as prime locations for loess deposition because of the availability of loose sediment, sparse vegetal cover, and moderate to strong winds. However, loess deposits are more commonly located in or near glacial regions. Glacial outwash debris containing sand, silt, and clay is transported to floodplains by rivers that drained glacial melt water. The glacial debris, primarily the silt and clay, become airborne via strong winds as vegetation is not present to hold sediment down.

Collapsible soil (loess) usually attains considerable depths, and the soil derived from it, is very fertile. There are large deposits in central Europe (Hungary), China, and North America. Much work on collapsible soil (loess) has been extensively described in the literature (e.g. [6-15]). They studied different samples from Europe, United states of America, South America, and Asia. However, the amount of data on collapsible soils (loess) from Saudi Arabia is significantly smaller.

\section{DISTRIBUTION AND COMPOSITION OF LOESS}

The distribution of collapsible soil (loess) shows that it is derived from three main sources: deserts, Pleistocene glacial outwash deposits, and the floodplains of rivers in semiarid regions. The world's largest loesscovered areas was found in China on the banks of the Huang Ho; on the margins of the continental deserts of Inner Asia. The thickest loess occurs in central China on the Loess Plateau [16], where it reaches a thickness of about $330 \mathrm{~m}$ near Lanzhou. in Central Asia, in Kazakhstan, Uzbekistan, the foreland of the Tien Shan, and east of the Caspian Sea; and in Siberia along Lake Baikal and the Lena River and in vast regions in the southern parts of the catchment areas of the $\mathrm{Ob}$ and Yenisey rivers.

In Europe there is an extensive, uninterrupted loess cover in the South Russian Plain, large spots and belts in the Danube Basin, along the Rhine, in Yugoslavia, along the margin of the former inland ice cap in the GermanPolish plain, about $13 \%$ of the territory of Bulgaria consists of collapsible loess soils, and in the Paris Basin. About $70 \%$ of the territory of Ukraine consists (morphologically) of flat land, almost completely covered with loess deposits. In North America loess covers the 
plains of the Platte, Missouri, Mississippi, and Ohio rivers and the Columbia Plateau. About $30 \%$ of the territory of United States of America is covered with loess deposits. In the Southern America, the most significant loess regions include the "pampas loesses" of Uruguay and Argentina and parts of New Zealand [17].

The composition of loess depends on the geology of the environment that it came from. A periglacial environment produces different materials than a desert and interior basin environment. Generally, loess is made up of minerals that include: quartz and feldspar as well as carbonate and clay minerals.

Natural loess in the northwest of the Loess Plateau in China showed that the main cement of loess aggregates is $\mathrm{CaCO} 3$. Loess Plateau, northern China analyzed for their mineral compositions. The results indicate that there is almost no difference between loess and paleosol in mineral composition. Major mineral species are quartz, mica, feldspar and chlorite, accounting for about $88-92 \%$ of the total; other minerals are kaolinite, smectite, vermiculite and a few heavy minerals.

\section{ORIGIN, OCCURRENCE, AND STRUCTURE OF COLLAPSIBLE SOILS(LOESS)}

Loess has been commonly considered as a product of subglacial grinding processes followed by redistribution and deposition by wind. One solution for the dispute on cold (periglacial) and hot (peridesert) origin would be to invoke a comparison between chemical and isotopic characteristics of loess. There is still a controversy regarding the existence of loess in deserts. Some researchers believe that loess is not found in deserts, even though deserts provide much of its material. In China as example where extensive deserts in central Asia which considered the source of loess and according to [18], the loess deposits in the central loess plateau chemically and isotopically resemble the desert loess deposits in the southwesttern tarim Basin but not in the north Tiashan. Accordingly, the loess in the plateau may have a source region in the takia makan desert but never in the north Tianshan.

Permeability of loess ranges between $10^{-2}$ and $10^{-4} \mathrm{~mm} / \mathrm{s}$, which is considered as low degree of permeability (According to [19]).

Loess has a metastable structure [20-22]. The structure of loess may be defined based on the manner of arrangement and state of aggregation of loess grains. Consideration such as mineralogical composition, orientation and shape of loess grains, nature and properties of its water and the interaction of this water and loess grains, also may be included in the study of loess structure. Honey-comb structure is characteristic of loess (figure1(a)) due to the relatively smaller size of grains, besides gravitational forces, inter-particle surface forces also play an important role in the process of settling down. The structure has a large void space and may carry high loads without a significant volume change. The structure can be broken down by external disturbances.
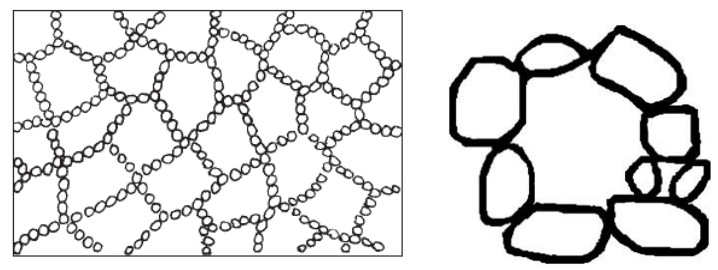

Fig.1. a) Honey-comb structure; b) Sketch of trellis pore.

Specifically, the structure arrangement of loess is not in a stable state, rather it is in transitional state with conditional stability. This permits loess structure to remain stable under some conditions, but may be unstable under others. Because of the significant effect 
of inter-particle forces, silt particles that are deposited under gravitational force rest on unstable contacts. As a result, the loess has a loose structure. Moreover, if several silt particles with unstable contacts join, pores larger than the particles size can be formed. This type of pore is called "trellis pore" in Chinese literature [13]. The metastable loose structure with trellis pores(figure1(b)) is primarily responsible for loess collapsibility. In China, loess formed during or before Middle Pleistocene of Quaternary Period is usually non-collapsible under wetting, because its structure is stabilized during the longer period of consolidation [23] and [24].

Loess has been commonly considered as a product of subglacial grinding processes followed by redistribution and deposition by wind. Some locations of periglacial loess are: Northern area of France, collapsible loesssic brickearth in Kent, United Kingdom [10], Russia [25], North America, Matanuska Valley of Alaska show loess deposition [26].

\section{TESTING MATERIALS}

The soil samples used in this study were obtained from the north of Najran region which is a province of Saudi Arabia, located in the south of the country along the border with Yemen as shown in figure 2. It has several valleys, the most famous of them being Najran's valley. It is encircled by a range of Rocky Mountains, the highest of which is the 1450-meter-high Abu Hamdan Mountain. The climate of Najran is hot during the summer months with an average value of 32 degrees Celsius and mild during the winter months. Temperatures in winter drop to an average of 6 degrees Celsius. It is rainy in the mountainous areas. The intensity of rain is about $52.9 \mathrm{~mm} /$ year in 2010 and it reached more than $274.2 \mathrm{~mm} /$ year during the year of 1996.

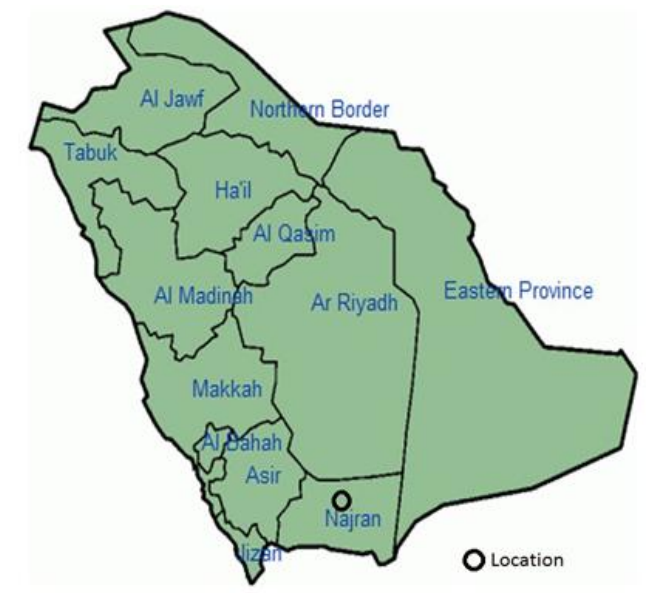

Saudi Arabia Map

Fig.2. Location map for the area of tested soil sample.

Figure 3 shows a typical soil profile ( borehole $\log$ ) of Najran soil.

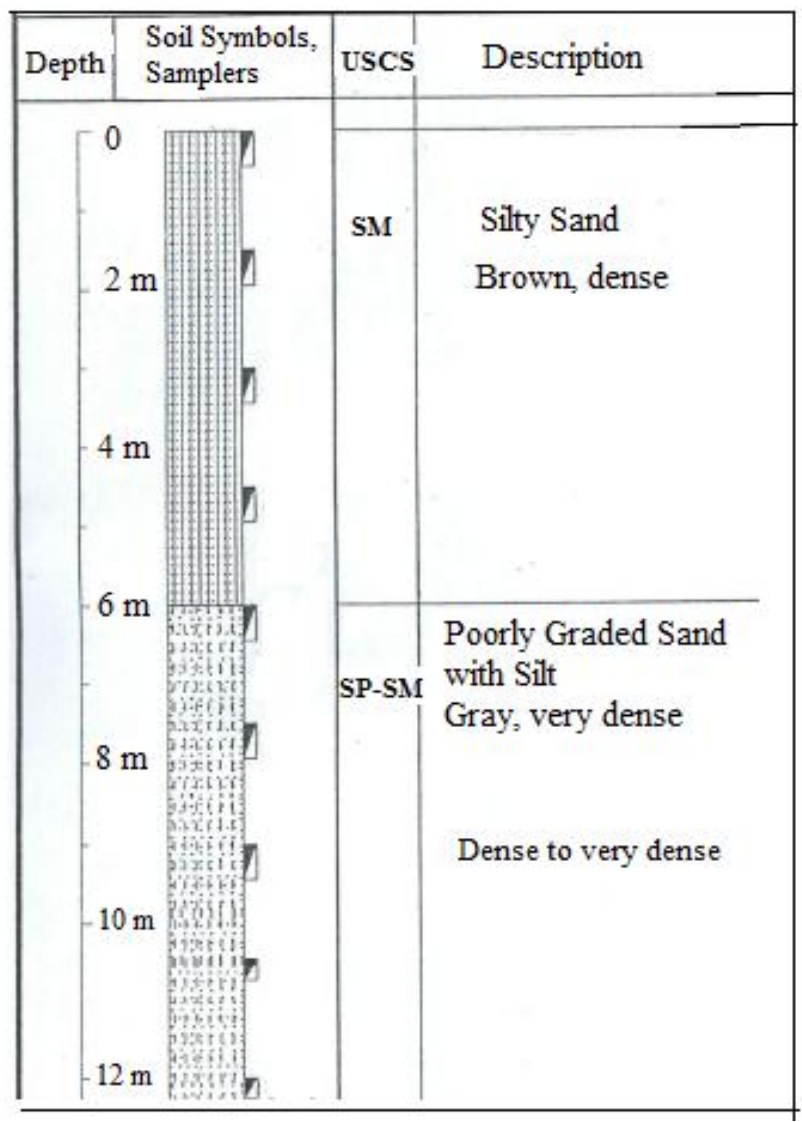

Fig. 3. Soil profile of Najran soil.

Undisturbed block samples of Najran soil were obtained from a depth of $3 \mathrm{~m}$. Samples have been manually extracted. The undisturbed samples were carefully trimmed, 
waxed and then taken to the laboratory for testing. The particle size distribution (figure 4 shows that the tested soil samples generally consists of $79.5 \%$ sand grains, $16.89 \%$ silt grains, and $3.61 \%$ clay particles. As shown in figure 5, Plasticity chart shows the results of Atterberg limits for the tested soil sample. By using the Unified Soil Classification System (USCS), the tested soil can be classified as silty sands (SM).

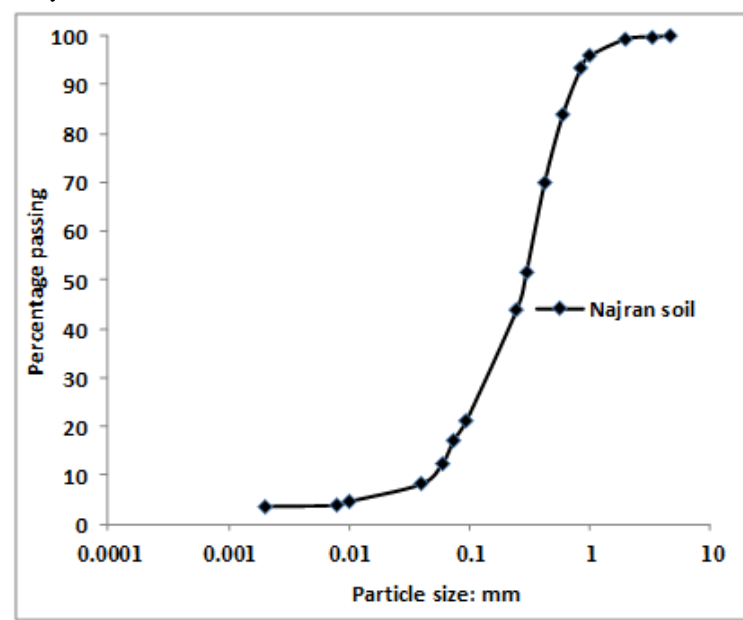

Fig. 4. Particle size distribution for tested Najran soil sample.

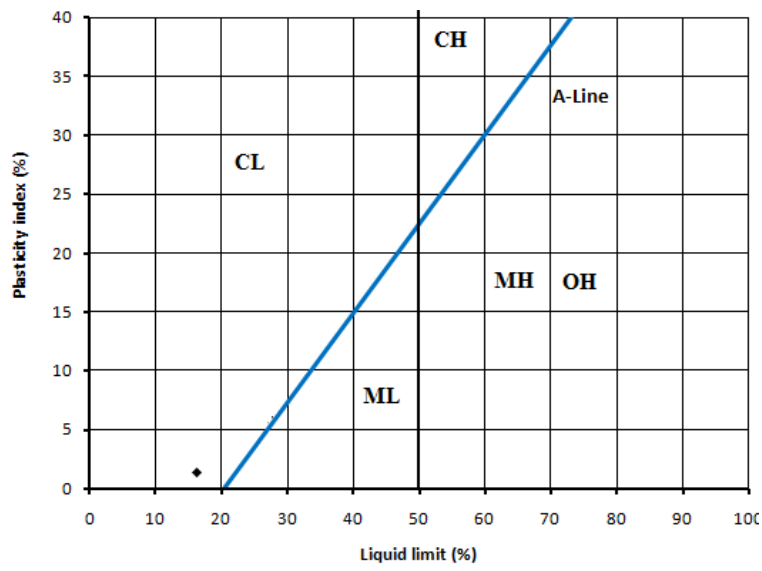

Fig. 5. Plasticity chart showing results of Atterberg limits on Najran sample.

The index properties, Atterberg limits, and mechanical analysis are presented in Tables 1 , 2 , and 3. It is worth noticing that the plasticity index $\mathrm{IP}=1.3$ (between 1 and 5), which means that the soil has a slight plasticity. The liquidity index for Najran soil is less than zero, the soil is brittle fracture when sheared. The consistency index of Najran soil is greater than one, the soil is in semi-solid state and is stiff.

TABLE 1: INDEX PROPERTIES OF NAJRAN TESTED SOIL SAMPLE.

\begin{tabular}{|l|c|}
\hline \multicolumn{1}{|c|}{ Property } & Results \\
\hline Moisture content $(\%)$ & 1.4 \\
Specific gravity & 2.71 \\
Bulk density $\left(\mathrm{g} / \mathrm{cm}^{3}\right)$ & 1.61 \\
Dry density $\left(\mathrm{g} / \mathrm{cm}^{3}\right)$ & 1.58 \\
Void Ratio, e & 0.715 \\
Porosity, n & \\
Degree of saturation, $\mathrm{S}$ & 5.3 \\
\hline
\end{tabular}

TABLE 2: ATTERBERG LIMITS OF NAJRAN TESTED SOIL SAMPLE

\begin{tabular}{|l|c|}
\hline \multicolumn{1}{|c|}{ Property } & Results \\
\hline Liquid limit (\%) & 16.60 \\
Plastic limit (\%) & 15.30 \\
Plasticity index (\%) & 1.3 \\
Liquidity Index (\%) & -10.7 \\
Consistency Index & 11.7 \\
\hline
\end{tabular}

TABLE 3: MECHANICAL ANALYSIS OF NAJRAN SOIL.

\begin{tabular}{|c|c|}
\hline Soil type & Percentage (\%) \\
\hline Sand (\%) & 79.50 \\
Silt (\%) & 16.89 \\
Clay (\%) & 3.61 \\
\hline
\end{tabular}

Figure 6 shows example of as expected as peridesert soil structure by using Scanning electron microscope (SEM) tests for undisturbed samples from Najran soil at depth of $3 \mathrm{~m}$. The results show clay matrices around the silt and sand particles, pore spaces are also shown which are probably responsible for the weaker zones. 


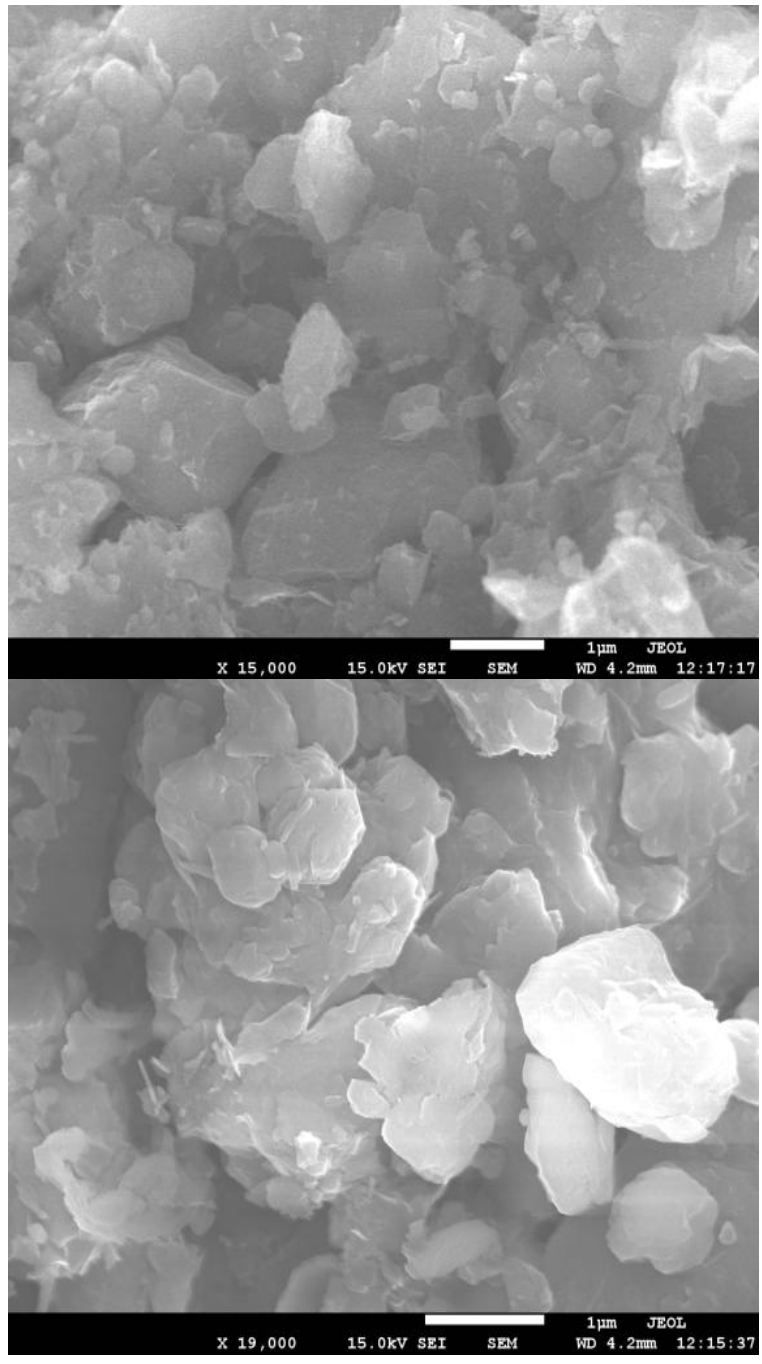

Fig. 6. Soil fabric as shown by scanning electron microscope (Najran Soil sample at natural moisture content).

\subsection{Mineralogy}

The $\mathrm{x}$-ray diffraction analysis and Energy Dispersive Spectrometry (EDS) for Najran soil show that the Najran soil is predominated by Quartz ( $\mathrm{SiO} 2)$, Potassium Aluminum Silicate $\mathrm{K}\left(\mathrm{Si}_{3} \mathrm{Al}\right) \mathrm{O}_{8}$, which is a group of Feldspars, and Calcium Magnesium Carbonate $\left(\mathrm{CaMg}\left(\mathrm{CO}_{3}\right)_{2}\right.$, which is a group of carbonates, and Aluminium Copper Titanium(AlCu2Ti). Concerning the clay fractions, kaolinite is the most abundant mineral of Najran soils, followed by Smectite, Illite, mica, Chlorites, and little amount of Montmorillonite. Figure 7 shows the X-ray diffraction for Najran soil.

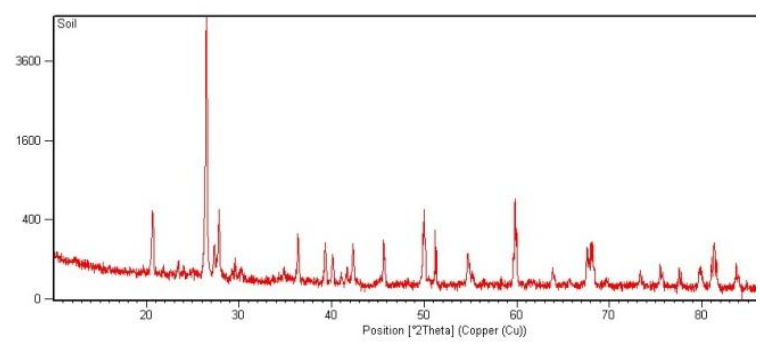

Fig. 7. X-Ray diffraction for Najran soil

\subsection{THE HYDROCOLLAPSE OF COLLAPSIBLE SOIL}

The mechanism of hydrocollapse, named also hydroconsolidation, or hydrocompression is based on the transformation of an unstable to a stable particle packing. The usual way for testing the hydrocollapse of collapsible soil is to test an undisturbed specimen in an Oedometer apparatus. The variations are initiated by interparticulate bond that will be destroyed if the water content increases. [27] was amongst the earlier researchers to suggest that the porosity of a soil may be connected with metastability; a soil may be metastable if it is capable of absorbing enough water to take it up to or past the liquid limit. [27] therefore suggested (equation 1) that a soil may be metastable if:

$\frac{\mathrm{e}_{\mathrm{L}}}{\mathrm{e}_{0}}<\mathbf{1}$

where $\mathrm{e}_{\mathrm{L}}$ and $\mathrm{e}_{0}$ are void ratios at the liquid limit and natural moisture content respectively.[1] defined the collapse potential (CP) as the deformation due to wetting and can be obtained through simple Oedometer tests according to the expression defined by equation (2):

$\mathrm{CP}=\frac{\Delta \mathrm{e}}{1+\mathrm{e}_{\mathbf{0}}} \times 100$

Where,

$\Delta \mathrm{e}-$ Void ratio variation caused by wetting.

$\mathrm{e}_{0} \quad$-Initial void ratio; $\mathrm{CP}-$ Collapse potential (\%). 
The collapsibility is evaluated using coefficient of collapsibility $\left(\boldsymbol{\delta}_{\mathrm{w}}\right)$ as defined by equation (3) [28].

$\boldsymbol{\delta}_{\mathbf{w}}=\frac{\mathbf{h}_{\mathbf{1}}-\mathbf{h}_{\mathbf{2}}}{\mathbf{h}_{\mathbf{0}}}$

In equation (3), $\boldsymbol{\delta}_{\mathrm{w}}$ : is coefficient of collapsibility, $\mathrm{h}_{0}, \mathrm{~h}_{1}$ and $\mathrm{h}_{2}$ are respectively the height of samples before consolidation, after consolidation and final height after the process of collapsibility fully occurred. Table 4 provides an indication of the potential severity of collapse, it indicates that those soils, which undergo more than $1 \%$ collapse potential can be regarded as metastable.

TABLE 4. COLLAPSE POTENTIAL [1], AS AN INDICATION OF POTENTIAL SEVERITY AT NORMAL STRESS OF 200 KPA.

\begin{tabular}{|ll|}
\hline Collapse potential (\%) & Severity of problem \\
\hline $0-1$ & No problem \\
$1-5$ & Moderate trouble \\
$5-10$ & Trouble \\
$10-20$ & Severe trouble \\
$>20$ & Very severe trouble \\
\hline
\end{tabular}

The phenomena of hydrocollapse of microstructure of collapsible soil (loess) after flooding(wetting) can take place as shown in figure 8 .

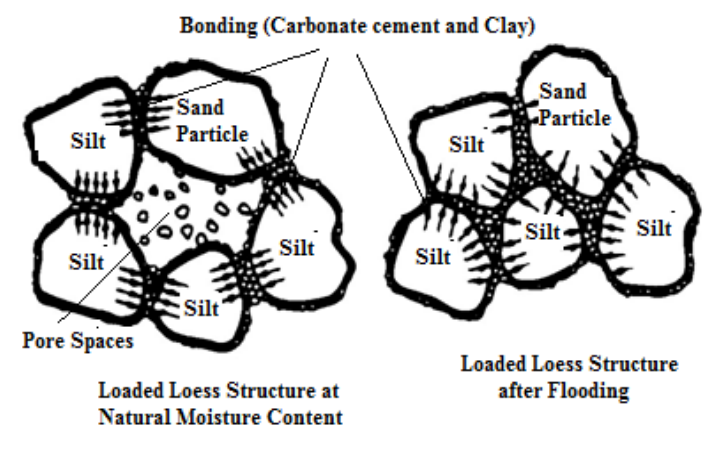

Fig.8. Hydrocollapse of microstructure of loess.
[28] stated that the most common method used to identify a collapsible soil, is the onedimensional compression test using an Oedometer. They reported that soil hydrocollapse is often determined for a stress of $300 \mathrm{kPa}$ and is given by equation (4):

$$
\mathrm{i}=\frac{\Delta \mathrm{e}}{1+\mathrm{e}_{1}}=\frac{\mathrm{e}_{1}-\mathrm{e}_{2}}{1+\mathrm{e}_{1}}
$$

Where,

$$
\begin{aligned}
& \mathrm{i}=\quad=\text { the coefficient of collapse } \\
& \Delta \mathrm{e} \quad=\text { decrease in void ratio caused by } \\
& \text { wetting } \\
& \mathrm{e}_{1} \quad=\text { void ratio before wetting } \\
& \mathrm{e}_{2} \quad=\text { void ratio after wetting }
\end{aligned}
$$

\section{EXPERIMENTAL PROCEDURES}

It is worth noticing that collapse upon wetting is a common geotechnical problem in natural arid and semi-arid region soils. Therefore it is important to study the semiarid Najran soil.

There are two alternative methods for collapse-potential determination, single Oedometer and double Oedometer tests as shown in figure 9. The double Oedometer test is carried out on two identically prepared samples, one tested at in-situ natural moisture content and the second is fully saturated before the test begins and then subjected to identical loading.

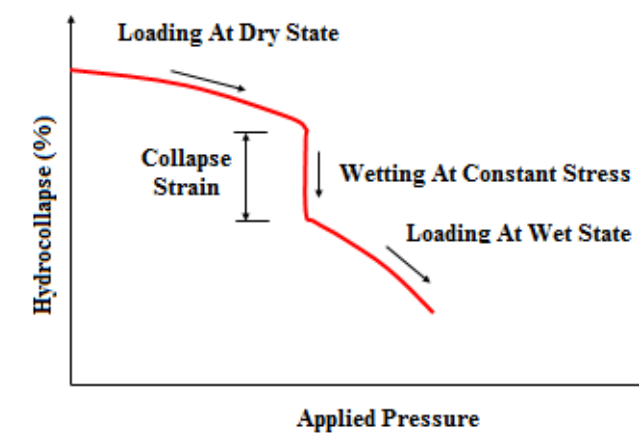

Fig.9. (a) Single Oedometer tests. 


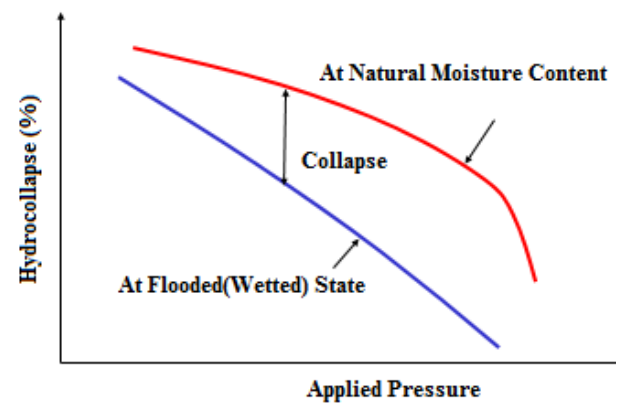

Fig. 9. (b) Double Oedometer tests.

Single oedometer and double oedometer tests were carried out to test the undisturbed Najran soil sample. The test specimen is 50 $\mathrm{mm}$ in diameter and $20 \mathrm{~mm}$ in height. The procedure of testing is as follows: the sample being carefully trimmed to size to fit snugly into the sample ring, the sample is then loaded, usually incrementally, to reach the stress required at wetting, which allows water to penetrate the sample via the top and bottom porous stones, and the change in height of the sample is monitored. Additional (incremental) loading can subsequently be applied to determine post-saturation deformation. This is a satisfactory test method but, of course, there is little control over the nature of the specimen. The standard test to determine hydrocollapse potential for a soil is the single Oedometer test with a stress reference at flooding of $200 \mathrm{kPa}$. The incremental loading sequence typically used in this study produced vertical stresses of 6,12 , $25,50,100,200,400,800$, and $1600 \mathrm{kPa}$. Load increments were added at 3 hour intervals to soils in their natural state and 4 hour intervals to soils once wetted. During the load increment at which flooding occurred, the sample was left untouched for 24 hours to ensure that collapse was completed. Double Oedometer tests were carried out on two identically prepared samples, one sample being loaded incrementally in its natural state and a second being wetted under the initial vertical stress of
$12 \mathrm{kPa}$ prior to incremental loading. This latter technique aimed to produce the upper and lower boundaries of behavior, thus allowing a prediction of the degree of hydrocollapse under normal stress level.

Cylindrical cutting ring has been used for trimming the sample down to the inside diameter of the Oedometer ring with a minimum of disturbance. Once inserted into the oedometer ring, filter papers were placed on both ends and the apparatus was assembled (BSI, 1991) [29]. The tests were carried out according to ASTM D 5333 [30].

\section{EXPERIMENTAL RESULTS AND DISCUSSIONS}

The results of double Oedometer test for Najran soil is shown in figures 10 and 11 . The magnitude of hydrocollapse of Najran soil resulting from wetting(flooding) equals $6.58 \%$ at pressures greater than $100 \mathrm{kPa}$ and equals $11.07 \%$ at pressure of $200 \mathrm{kPa}$ and the maximum hydrocollapse reaches $17.02 \%$ at pressure of $1600 \mathrm{kPa}$.

It is worth noticing that compression was insignificant in the "dry" (natural water content) state when compared to the collapse settlements due to wetting. It was also evident from the e- $\log \sigma$ curve as shown in figure 10(b) that the sample showed unique natural state and post-wetted relationship between void ratio and applied pressure, thus implying that a double oedometer test would produce accurate predictions of collapse over the full range of vertical stresses. The post-wetted e- $\log \sigma$ curve at the end became approximately linear.

Results of a single Oedometer test on undisturbed Najran soil is presented in figure 12. At a stress level of $200 \mathrm{kPa}$ the degree of hydrocollapse was found to be approximately $10.24 \%$, whereas the maximum value exceeds $16.03 \%$ at pressure of $1600 \mathrm{kpa}$. 


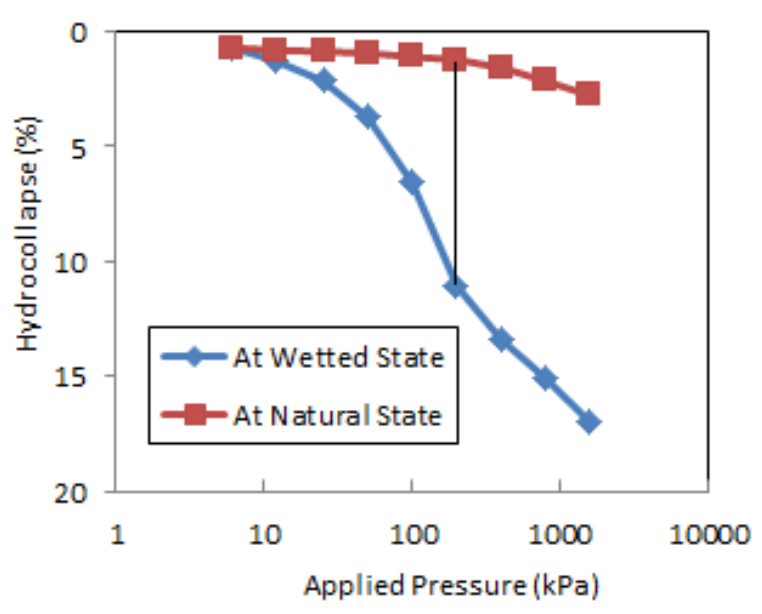

Fig.10. Hydrocollapse Versus Applied pressure from Double Oedometer test.

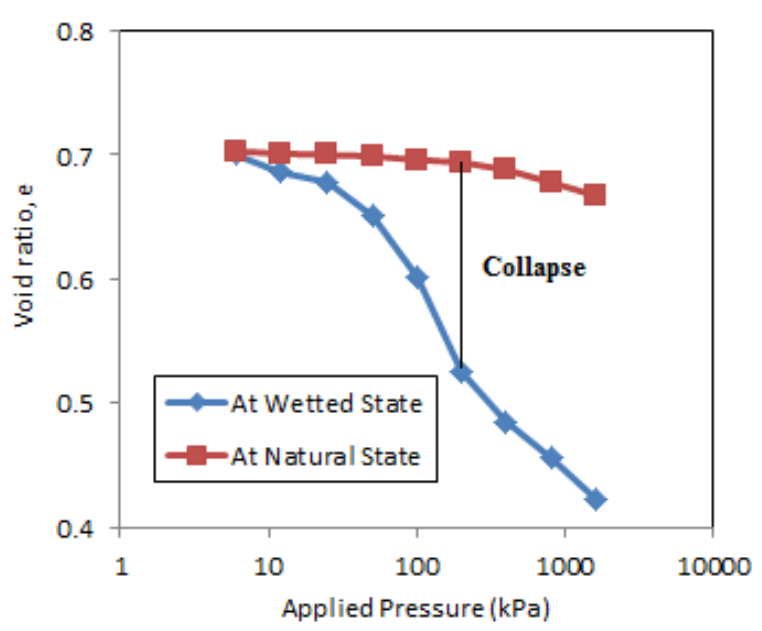

Fig. 11. Relationship between Void Ratio and Applied pressure of undisturbed Najran soil sample from Double Oedometer test.

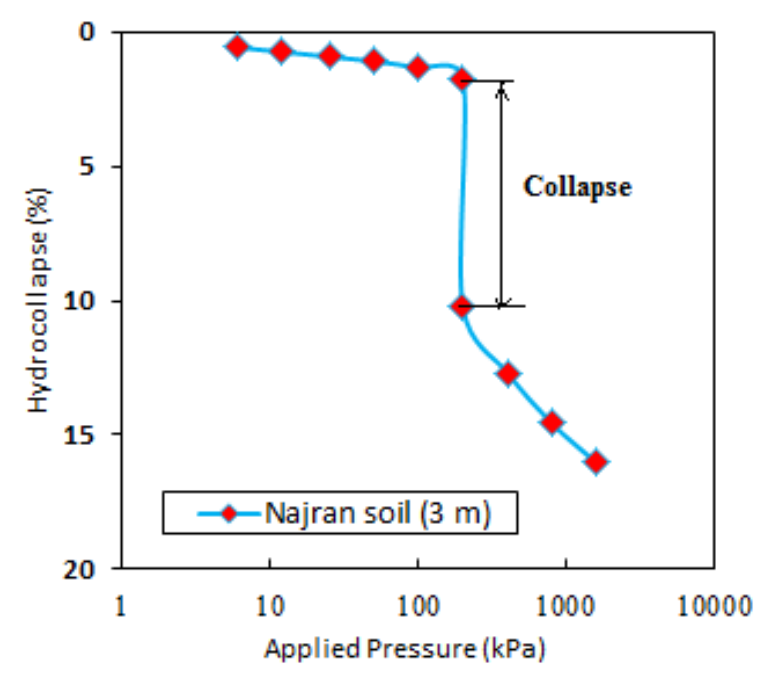

Fig. 12. Correlation between degree of hydrocollapse and applied stress at $200 \mathrm{kPa}$ wetting from single Oedometer tests.
Figure 13 shows the relationship between void ratio and applied stress of undisturbed Najran $\operatorname{soil}(3 m)$.

The relationship between void ratio and applied stress of undisturbed Najran soil shows also that the post-wetting curves indicate that saturation at lower applied stresses between $12 \mathrm{kPa}$ and $50 \mathrm{kPa}$ does not fully destroy the bonds, with the relatively open structures being maintained up to applied stresses of at least $100 \mathrm{kPa}$. After the stress of $100 \mathrm{kPa}$, the saturation will destroy the bonding between silt/silt or silt/sand particles and the collapse is more significant.

The Najran soil exhibited high amount of collapsibility. This high collapsibility may due to the small amount of clay fraction which provides a weakness to the particle cementation and also provides a large-sized pores in an open arrangement to the soil structure. The high amount of sand in Najran soil can also play a role by allowing the pores to be more larger through the microstructure. This explanation indicates good agreement with [31] who examined in a detailed the microstructure of loess soils in Russia. He found that the coarser grains were never in contact with each other, being carried in a fine granular dispersed mass. Hence, the strength of the soil is largely determined by the character of this fine mass.

Figure 14 shows the Soil fabric by scanning electron microscope (Najran Soil (3m) consolidated without flooding. The fabric observed as more dense when applying pressure at dry state.

Figure 14 shows the Soil fabric by scanning electron microscope (Najran Soil (3m) consolidated without flooding. The fabric observed as more dense when applying pressure at dry state. 


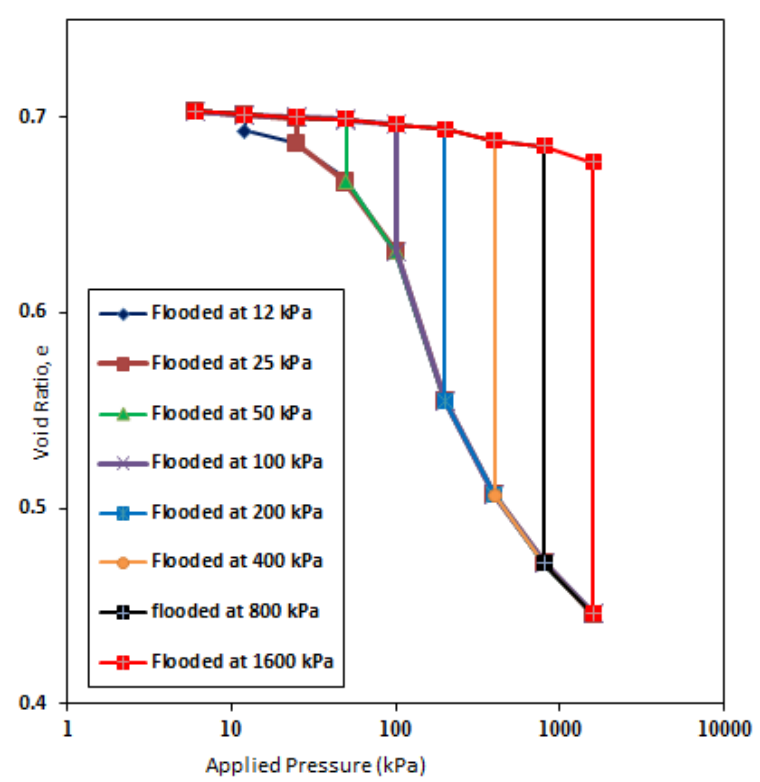

Fig.13. Relationship between void ratio and applied stress from double Oedometer tests.
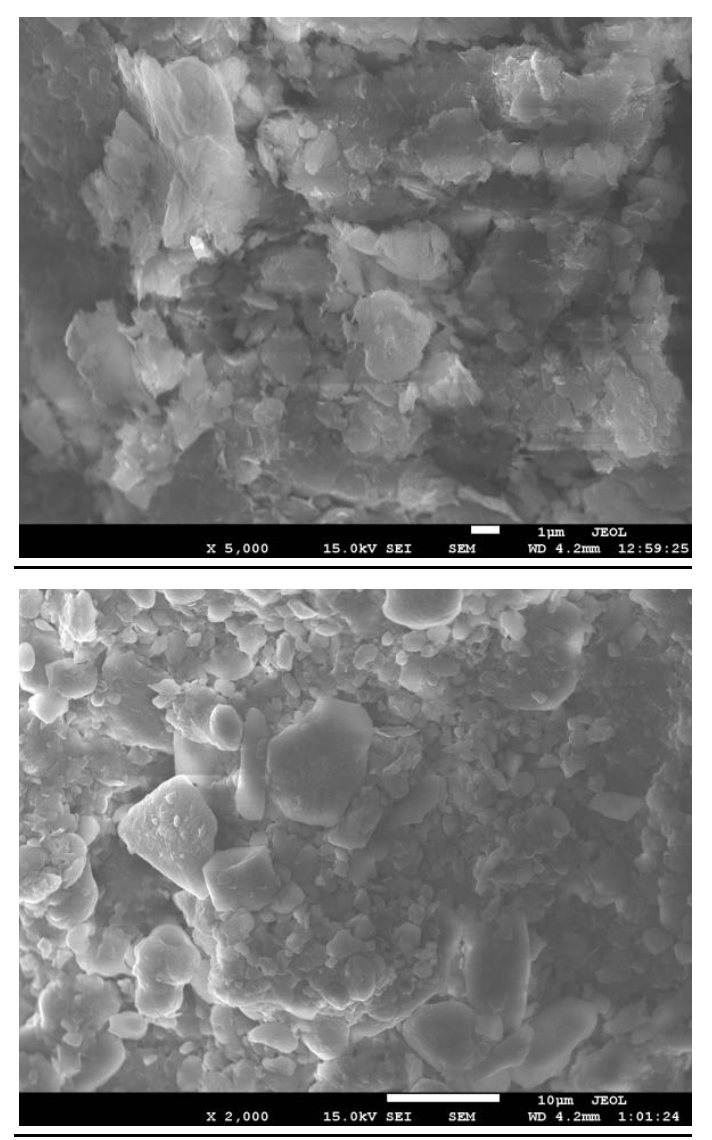

Fig.14. Soil fabric as shown by scanning electron microscope (Najran Soil sample consolidated without flooding.
According to [1], collapse potential of Najran soil as an indication of potential severity at normal stress of $200 \mathrm{kPa}$ is shown in table 5 .

TABLE 5: COLLAPSE POTENTIAL [1], OF THE UNDISTURBED NAJRAN SOIL AS AN INDICATION OF POTENTIAL SEVERITY AT NORMAL STRESS OF $200 \mathrm{KPA}$.

\begin{tabular}{|c|c|c|}
\hline Najran soil (3m) & $\begin{array}{c}\text { Hydrocollapse } \\
\text { values (\%) }\end{array}$ & $\begin{array}{c}\text { Severity of } \\
\text { problem }\end{array}$ \\
\hline $\begin{array}{c}\text { Single } \\
\text { Oedometer Test }\end{array}$ & 10.24 & Trouble \\
\hline $\begin{array}{c}\text { Double } \\
\text { Oedometer Test }\end{array}$ & 11.07 & severe trouble \\
\hline
\end{tabular}

The Standard Proctor test (ASTM D 1557)[32] was conducted to determine the optimum moisture content (OMC) and the maximum dry unit weight $\left(\boldsymbol{\gamma}_{\mathrm{dmax}}\right)$. Figure 15 shows the standard proctor compaction curve. The optimum moisture content (OMC) was found to be equals $8.6 \%$ and the maximum dry density was also found to be equals 1.96 $\mathrm{g} / \mathrm{cm}^{3}$.

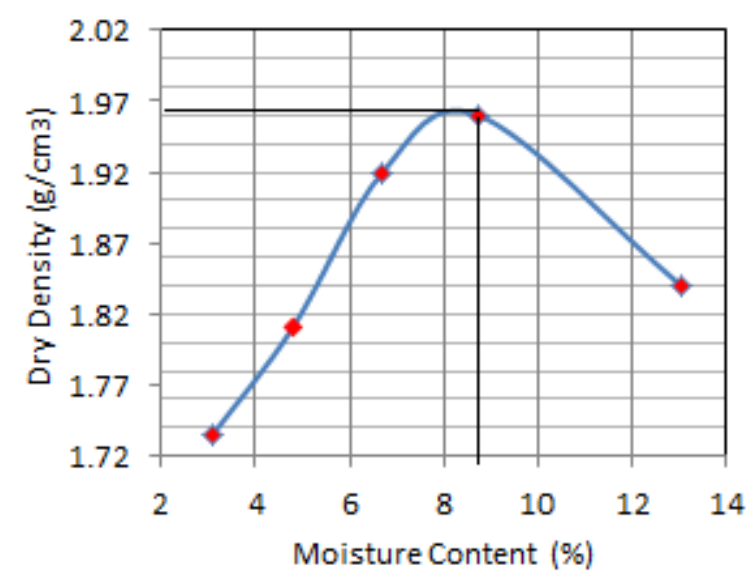

Fig. 15. Standard proctor compaction curve for Najran soil sample. 


\section{CONCLUSION}

The following conclusions have been drawn from this study :

It is generally accepted that double Oedometer test is useful in observing the difference in compression characteristics between sample at natural moisture content and the same sample after flooding at different stress levels. Single Oedometer test provided the most appropriate method of obtaining the degree of hydrocollapse for collapsible soils. The results from the double Oedometer test provides collapse potential values greater than the values given by the single Oedometer test.

Hydrocollapse was insignificant at the dry (natural water content) state when compared to the collapse settlements due to flooding. Hydrocollapse of Najran soil can be explained by the phenomena of wetting as a result, the destruction of clay bond between particles and the soil becomes soft, which can lead to the collapse of the metastable structure.

The mechanism of bonding in Najran soil plays a great role in defining the nature and degree of hydrocollapse. The stability of the open metastable particle structure of Najran soil depends to a large degree on the interparticle bonding. The relative severity of the collapse potential of Najran soil was determined using the relation defined by [1] The correlation between applied pressure and collapse potential was found not linear. The amount of collapse potential was found to vary with both applied pressure and the void ratio. The collapse potential of the undisturbed Najran soil pose a severe trouble problem for both single and double oedometer tests, according to the criteria given by [1].

\section{ACKNOWLEDMENT}

This research work is supported by the Deanship of Scientific Rsearch at Najran University, Saudi Arabia.

\section{REFERENCES}

[1] Jennings, J.L., and knight, K.,. "A guide to construction on or with material exhibiting additional settlement due to collapse of grain structure", In proceedings of the $6^{\text {th }}$ Regional Conference for Africa on Soil Mechanics and Foundation Engineering, Durban, South Africa, pp. 99-105, 1975.

[2] Mulvey, W.E.,"Engineering geologic problems caused by soil and rock in southwestern Utah", in Harty, K.M., editor, Engineering and Environmental Geology of Southwestern Utah: Utah Geological Association Publication 21, pp. 139-144, 1992.

[3] Rollins, K.M., Williams, T., Bleazard, R., and Owens, R.L., "Identification, characterization, and mapping of collapsible soils in southwestern Utah", in Harty, K.M., editor, Engineering and Environmental Geology of Southwestern Utah: Utah Geological Association Publication 21, pp. 145-158, 1992.

[4] Krutov, V.I., "Foundation construction on collapsible soils", Mechanics and foundation engineering, vol. 24, Number 6,pp. 9-11, 1987.

[5] Rogers, C.D.F,. "Types and Distribution of Collapsible Soils", Keynote Paper, Proc. of NATO Workshop on Collapsible Soils, published by Kluwer Academic Press, p p.1-17, 1995.

[6] Smalley, I.J., and Cabrera, J.G., "The shape and surface texture of loess particles", reply. Geol. Soc, Amer., 82, pp. 2361-2364, 1971.

[7] Rogers, C. D. F. and Smalley, I. J., "The shape of loess particles", Springer Berlin / Heidelberg, Short Communication, Volume 80, Number 10, pp. 461-462, 1993.

[8] Rogers, C. D. F., Dijkstra, T.A., and Smalley, I. J., "Hydroconsolidation and subsidence of loess: studies from China, Russia, North America and Europe", Engineering Geology, 37, pp. 83-113, 1994.

[9] Northmore, K.J., Bell, F.G. and Culshaw, M.G.,"The engineering properties and behavior of the brickearth of south Essex", Quaterly 
Journal of Engineering Geology, 29, pp. 147-161, 1996.

[10] Jefferson, I., Evstatiev, D., Angelova, R., and Smalley, I.J., "Improvement of loess soils in north-west Bulgaria for radioactive waste disposal", Proc. $2^{\text {nd }}$ Int. Conf. On Ground improvement techniques, Singapore, pp. 207-212, 1998.

[11] Mellors, T.W., "The influence of the clay component in loess on collapse of the soil structure" In Genesis and Properties of Collapsible Soils, 207-216, E. Derbyshire et al. eds, Kluwer Academic Publishers, 1995.

[12] Lin, C.Y., "Structure of loess. Symposium on basic properties of loess", Civil Engineering and Architecture Institute of Chinese Academy of Sciences, Science Press, Beijing, 1960.

[13] Evstatiev, D., "Design and treatment of loess bases in Bulgaria. In Genesis and Properties of Collapsible Soils", 375-382, E. Derbyshire et al. eds, Kluwer Academic Publishers, 1995.

[14] Pye, K., " Aeolian Dust and Dust Deposits", Academic Press, London, 1987.

[15] Gao. G., The distribution and geotechnical properties of loess soils, lateritic soils and clayey soils in China. Engineering Geology, Volume 42, Issue 1, pp. 95-104, 1996.

[16] Zheng Honghan, B. K. G. Theng, and Whitton, J.S., "Mineral composition of Loess-Paleosol samples from the Loess Plateau of China and its environmental significance", Science Press, copublished with Springer-Verlag GmbH, volume 13, number 1, pp. 61-72, 1993.

[17] Encyclopædia Britannica, "loess", Inc., 2012.

[18] Liu, C.Q., Okada, A. and Yabuki, S., "Riken Review", No. 5, Focused on Earth and Planetary Environment, 1994.

[19] Terzaghi. K., and Peck. R.B.,"Soil Mechanics in Engineering Practice", John Wiley and Sons, Inc., 1948.

[20] Barden, L., A. McGown, A., and Collins, K., "The collapse mechanism in partly saturated soil', Engineering Geology 7 (1), pp. 49-60, 1973.

[21] Dijkstra, T.A., Smalley, I.J., and Rogers, C.D.F., "Particle packing in loess deposit and the problem of structure collapse and hydroconsolidation", Engineering Geology 40, pp. 49-64, 1995.
[22] Assallay, A.M., Rogers, C.D.F., and Smalley, I.J., "Formation and collapse of metastable particle packing and open structures in loess deposits", Engineering Geology 48, pp. 101-115, 1997.

[23] Qian, H. J., Wang, J.T., and Luo, Y.S., "Collapsible Loess Ground", China Architecture \& Building Press, Beijing, 1985.

[24] Zhang, Z.Z., "Predication and countermeasures of the loessial seismic subsidence disaster in Xigu district, Lanzhou City", Northwestern Seismological Journal 19, Supplement Edition, 1997.

[25] Abelev, M. Yu., "Compacting loess soils in the USSR". Géotechnique, 25, pp.79-82, 1975.

[26] Daniel, R. Muhs., John, P. Mcgeehin., Jossh, Beann and Eric, Fisher., " Holocene loess deposition and soil formation as competing processes, Matanuska Valley, southern Alaska", Quaternary Research, Volume: 61, Issue: 3, pp.265-276, 2004.

[27] Denisov, N. Ya., "The engineering properties of loess and loess-like soils (in Russian)", Moscow (Gosstroiizdat), pp.133, 1951.

[28] Yuan, Z.X. and Wang, L. M., "Collapsibility and seismic settlement of loess”, Engineering Geology, 105, pp. 119-123, 2009.

[29] Lutenegger, A.J, Hallberg, G.R., "Stability of Loess", Engineering Geology, Vol. 25, pp. 247261, 1988.

[30] British Standards Institution, BS 1377,"Methods of testing soils for civil engineering purposes, BSI, London, 1991.

[31] ASTM D 5333: Test Method for the Measurement of Collapse Potential of Soils

[32] Larionov, A.K., "Structural characteristics of loess soils for evaluating their constructional properties", Proc. Of the 6 International Conference on Soil mechanics and Foundation Engineering. Vol. 1, Montreal (Canada), pp. 6468, 1965.

[33] ASTM D 1557, Standard Test Methods for Laboratory Compaction Characteristics of Soil Using Modified Effort. 


\section{الخصائص الجيوتقتية لتربة نجران، المملكة العربية السعودية \\ عمار روايقية و محمد داهم \\ قسم الهندسة المدنية، كلية الهندسة، جامعة نجر ان، المملكة العربية السعودية}

الملخص:

التربة القابلة للهبوط تنكون من مو اد سائبة، جافة، منخفضة الكثافة بحيث تتهار و تتماسك بموجب اضافة الماء أو التحميل الزائد. و هذه التربة موجودة في جميع أنحاء العالم، وتحديدا في المناطق الرسوبية، وتدفق الرواسب ، و اللوس Loess و هي عبارة عن تربة مترسبة بالهو اء. و يمكن تلخيص بأن الأهداف الرئيسية لهذه الدراسة هي وصف خصائص و سلوكيات التربة القابلة للهبوط مثل: المنشأ والمظهر و التركيب و مكوناتها. تبحث هذه الدر اسة في خصائص الانهيار وسلوكيات هذه المواد مع إثـارة خاصة إلى مدى تأثنير ها عند تعرضها للبلل تحت تأثثر مختلف مستويات الإجهادات .و تم جمع عينات من التربة الغير مقلقله من منطقة نجران وتقع في جنوب المملكة العربية السعودية ـ و تم دراسة هذه التربة باستخدام اختبارات الأودومترoedometer المنفرد و المزدوج ـ وأظهرت النتائج أن أعلى قيمة لطاقة الانهيار هي ( CP=11.07\%) حسب نتائج الأودومنر المزدوج و التي تمثل مشكلة خطيرة وفقا للمرجع [1]. 